Expressive and Instrumental Voting:

The Scylla and Charybdis of Constitutional Political Economy

\author{
Eric Crampton \\ University of Canterbury \\ Andrew Farrant \\ George Mason University
}

Draft June 23, 2003. Do not cite without permission.

Corresponding author: Eric Crampton. 2327 Freetown Ct 1B, Reston, VA 20191-1780. Ph. 703-476-9615. Fax 703-993-2323. ecrampto@gmu.edu 
I. Expressive Voting and the Feasibility of Constitutional Political

\section{Economy ${ }^{1}$}

Who governs the governors? Classical political philosophers and modern constitutional political theorists alike quest for an external authority immune to the temptations of self-interest. In the absence of angels to oversee the benevolent operation of government, constitutions serve to constrain both the range of policy options and the processes by which policies can be adopted. Constitutions, however, are not bequeathed to us from the heavens; they are written by individuals as subject to the workings of self-interest as are the politicians who will later be bound by them. ${ }^{2}$ The normative status of the constitutional endeavour then becomes problematic.

Constitutional political economists following in Buchanan's path solve the problem by specifying that constitutional issues are of a different sort than those encountered in workaday politics. Because constitutional politics involve issues of rule-making, those involved in the constitutional process cannot be certain of their eventual position in the post-constitutional phase. The nature of constitutional deliberation raises a veil of uncertainty between the authors of a constitution and their interests. Behind this veil, all citizens to be governed by a constitution can agree on a specific set of rules to apply in the post-constitutional phase. Absent the veil, agreement could not be achieved; constitutional matters would prove as contentious as everyday politics. The veil allows a contractarian turn where hypothetical agreement becomes the norm.

The veil of uncertainty has proven an effective mechanism for separating the designers of the constitution from their interests. We argue here that the veil proves too effective; environments in which 
individuals are separated from their interests are precisely those in which we can expect expressive preferences to reign. Brennan and Hamlin (2002) caution as much. The expressive voting critique is devastating to the constitutional enterprise, though Brennan and Hamlin do not take the argument to its necessary conclusion. In any veil setting, expressive preferences will trump interests and constitutions will at best be of no practical consequence. Removing the veil prevents expressive preferences from dominating, but only at the cost of reintroducing the problem of instrumental interests and diminishing the normative position assigned to the constitution.

The question of constitutional enforcement then comes to the fore. The workings of enforcement in the post-constitutional phase will depend greatly on whether the constitution was formed behind a veil or in the absence of the veil. Specifically, any constitution formed behind a veil will simply reflect the pre-existing expressive preferences of the electorate. Removing the veil negates the possibility of contractarian agreement and erodes the normative position of the constitution. The constitution must then be enforced over the objections of at least some citizens. When the authors of the constitution are not separated from their interests, either the constitution can bind and its authors give us Leviathan, or it cannot bind and is irrelevant.

II.

Expressiveness and the Constitutional Veil

Constitutional choice in any kind of participatory constitutional process cannot be insulated from the expressive voting critique raised against the workings of in-period electoral choice, as Brennan and Hamlin cogently argue. Expressive voting theory holds that voters maximize utility over both 
instrumental and non-instrumental factors. Instrumental preferences here refer to positively signed arguments in the utility function that provide an increase in utility if policy $\mathrm{X}$ is enacted as legislation. Expressive preferences, by contrast, are those arguments in the utility function that cause an increase in utility simply by the act of voting for policy X, regardless of whether X actually obtains as a result of the election. For example, a worker in the oil industry would see his instrumental interests advanced if arctic drilling restrictions were lifted; if that same worker were also an environmentalist, however, voting against the lifting of drilling restrictions may generate expressive benefits for him. Since any instrumental benefits from voting accrue only with an infinitesimal probability ${ }^{3}$ (equal to the probability that the individual voter will be decisive), non-instrumental expressive benefits will surely trump instrumental benefits in the voting calculus. Voters in any reasonably-sized electorate effectively make their electoral choices behind a "veil of insignificance."4

Expressive voting severs any connection that might exist between democratically-approved policies and efficient outcomes. Indeed, many voters can quite rationally vote for policies that lie directly in opposition to their narrowly instrumental interests if they derive expressive benefits from supporting those policies. As Caplan $(2000,2001)$ argues, voters in this context can readily be viewed as rationally irrational. The lack of any decisive connection between the voter's choice and policy outcomes allows any voter to costlessly entertain whatever biased model of the world they prefer. Caplan specifies that voters have preferences over beliefs about the world. While biased beliefs prove quite costly in an individual's day-to-day life, ${ }^{5}$ biased beliefs in the political realm can be entirely individually costless. It costs the individual voter nothing to believe that tariffs make Americans better 
off; the individual voter is never decisive in implementing policy. Voters can then rationally hold beliefs that are inconsistent with reality; they are rationally irrational.

Brennan and Hamlin recognize that voters at the constitutional level are even more individually insulated from the consequences of their voting decisions than they are at the level of in-period electoral politics. The veil of uncertainty characteristic in constitutional political economy accounts of decisionmaking at the stage of constitutional choice (Buchanan and Tullock, 1962) effectively truncates instrumental considerations from the voter's decision-making. While the hypothetical Veil of Uncertainty insulates constitutional choice from the instrumental interests of the choosers, it offers no similar protection against their expressive preferences; indeed, the expressive preferences that dominate in-period politics will entrench themselves in the constitutional phase.

Lack of decisiveness in any voting situation places voters, whether in-period or at the constitutional phase, behind a Veil of Insignificance. Choice behind this Veil can be made with utter disregard for the consequences of implementing any expressed preferences. Invocation of the contractarian unanimity norm does little to restore decisiveness; as Brennan and Lomasky (1993) point out, in any reasonably sized electorate where expressive and instrumental interests diverge, the probability of decisiveness remains low - any individual exercising a veto renders all other vetoes superfluous. The unanimity norm is then subject to the expressive voting critique and non-instrumental preferences are given free reign.

To the extent that constitutional issues tap into deeper feelings of "how the world ought to be" than do general in-period political issues, we can expect the expressive salience of constitutional issues 
to be even stronger than is the case in everyday in-period politics. Successful politicians wrap their otherwise workaday policy proposals in expressively-appealing packaging. As example, a California referendum on highly technical differences between alternative automobile insurance reform proposals can quickly turn into an opportunity for voters to register their support for "the little guy" against "big corporate interests" or for "honest businessmen" against the "trial lawyers". Building expressively appealing packaging for legislation is a massively important part of in-period politics.

At the constitutional phase, the issues at stake come expressively pre-packaged. The bread and butter of constitutional politics are issues that inherently have expressive appeal. Questions of rights and justice are enshrined in constitutions around the world. ${ }^{6}$ Turnout in constitutional referenda is typically strong, even though this very fact militates against the possibility that any voter's input can be decisive. Expressive politics must permeate any constitutional deliberation.

We suggest that the constitutional endeavour lies in steering a coherent path between the Scylla of expressive preferences that emerges a fortiori behind the veil of uncertainty and the Charybdis of narrow self-interest that dominates whenever the veil is withdrawn from the constitutional committee. Brennan and Hamlin attempt to navigate these dangerous waters by recommending that constitutional choice be delegated to groups sufficiently small in size to ensure that decision-makers remain decisive (thus avoiding expressive voting), yet sufficiently statistically representative of the overall population to eliminate the workings of interest group politics.

We suggest that no navigable waters lie between these shoals. In one scenario, the constitutional ship sails behind the veil and is dashed against the expressive preferences of its navigators. 
In the other, its navigators have full knowledge of the waters ahead and run full bore towards the pursuit of expected instrumental interests, to the ruin of everyone else. The ship founders in either case.

The constitutional Veil of Uncertainty works to reinforce the Veil of Insignificance characteristic in any large-number collective choice situation. Since the Veils work to isolate voters at the constitutional phase from whatever latent instrumental interests they might have had, expressive preferences will prove all the more focal in constitutional politics. Brennan and Hamlin argue that expressive considerations militate against the use of direct democracy or other forms of mass politics in the constitutional process and argue instead for a hybrid system in which a small group designs a constitution to be ratified by popular assent. Unfortunately, their proposed solution fails to satisfy. III. Small constitutional settings - the return of instrumental interests

To avoid the expressiveness concerns that will otherwise dominate constitutional politics, Brennan and Hamlin recommend that constitutions be designed by small constitutional conventions of statistically-representative individuals. By making individuals decisive players in the constitutional process, Brennan and Hamlin hope to raise the Veil of Insignificance from constitutional deliberations. All elements of popular voting must be removed from the selection of delegates to the Constitutional Convention to insulate delegates from the expressive preferences of the electorate. Small conventions can be populated by lot, in similar fashion to the selection of juries. ${ }^{7}$

A convention that is small enough in size such that each member considers himself a decisive chooser is also, however, a convention that can prove quite prone to the narrow instrumental interests 
of its constituent members. ${ }^{8}$ Even if the selection procedure is such that the normal interests of the members of the convention are quite reflective of the normal interests of the general populace, their status as members of the Constitutional Convention immediately provides them with a new interest that of maximizing the instrumental interests of the members of the Convention in the post-Constitutional society. ${ }^{9}$

Faced then with the problem of constitutional design as a small group decision process with no veil of insignificance separating the designers from their in-period interests, Brennan and Hamlin solve the problem in the following way:

$[\mathrm{H}]$ ere the standard interpretation of the constitutional move comes to the rescue. Since the questions faced by the convention members are, by definition, of a constitutional nature, the basis of their considerations will shift from narrow or direct self-interest to more general interests. Provided the membership is tolerably representative in a straightforwardly statistical sense, we should be able to rely on their deliberations as being both immune from highly partial self-interest and embodying the appropriate balance between expressive and instrumental considerations. (p.305)

In other words, they do not solve the problem at all. ${ }^{10}$ Indeed, if the weightiness of constitutional considerations is sufficient to cause the abandonment of instrumental self-interest, why can it not equally trump the lure of expressive self-interest? 
Absent expressive considerations, constitutional political economy faces the difficult problem of devising mechanisms separating the framers of the constitution from their in-period interests (let alone separating them from their interest in setting themselves up as Oligarch). The most effective theoretical mechanism has been the use of the Veil. Note of course that the Veil need not simply be theoretical; a stipulation that the new Constitution enacts only affer a two generation delay should be sufficient to separate all but the most foresighted from their interests. ${ }^{11}$ However, once expressive considerations are brought to bear, any Veil mechanism ${ }^{12}$ must either be ruled out entirely, or accepted only under the caveat that inefficiencies due to expressive preferences are preferable to the dangers of allowing interests free reign.

Brennan and Hamlin rely strongly on the standard "constitutional move" in their appeal to the use of a small, statistically representative committee to solve the joint problems of interest and expressiveness. In the standard move, the general nature of constitutional matters and uncertainty regarding one's own position in the post-constitutional phase ensure that the general interest is given preeminence in the constitution. However, the Veil mechanism serves to obviate an additional concern; namely, that the members of the constitutional committee might seek to maximize the position of the committee in the post-constitutional society. Absent the Veil, the standard "constitutional move" does not prevent the committee from establishing itself as Oligarch. Even if blatant oligarchy is ruled out, a host of other mechanisms are available. For example, the Committee could designate itself as a Constitutional Court which rules on the constitutionality of all legislation in the post-constitutional phase (indeed, who would be better as arbitrator over constitutional matters than its authors?). 
Within Brennan and Hamlin's framework, requirements of general assent to the devised constitution prevents the constitutional convention from establishing itself as oligarch; however, this same requirement also makes the general citizenry a veto player in the process and consequently provides a route by which the expressive preferences of the electorate will become constitutionally enshrined. ${ }^{13}$ Simply put, the electorate can commit to veto any proposed constitution that does not embody its expressive preferences. To the extent that the constitutional committee can deviate from the expressive preferences of the electorate, the committee can and will use that slack to further its own interest in establishing itself as oligarch rather than use it to promote the general interest. The process is best understood through example.

IV.

Tales of Brave Ulysses

The tale of Ulysses and the Sirens is the founding myth of constitutional political economy (see Brennan and Kliemt 1990). The benefits of the constraints placed upon Ulysses provide a reasonable allegory for the benefits of constitutional constraints upon the power of government (Elster, 2000). Placing Ulysses on an expressively governed ship illustrates the infeasibility of expressive constitutionalism.

Ulysses sails the seas near the domain of the Sirens. The Sirens' song is beautiful. Instead of simply enjoying hearing the sirens' call, our intrepid sailors also greatly enjoy telling everyone willing to listen exactly how much they love the sirens song. Telling all and sundry of one's love for the sirens' song provides each sailor with expressive utility. By telling of their love for the sirens' song, they signal 
their bravery to other sailors, for surely only the bravest of men would dare venture near the sirens simply to hear their song. Unfortunately, all who come within range of the sirens' call face a high probability of being devoured. Hearing the sirens' song gives the sailors a large amount of instrumental utility, whereas being eaten, however, markedly reduces their utility. Also near the sirens' island lies an island of slavers. Slavers are known to pay good money for new slaves, especially for ones with great feats to their names like Ulysses' men. The path between the sirens and the slavers leads home to Greece.

How then shall our sailors plot their course? The plotting of the course is akin to a constitutional convention $^{14}$; the tale of Ulysses and the sirens is the mythology of Constitutional Political Economy. Prior to plotting their course, however, the sailors must engage in meta-constitutional choice: namely, the choice of how to choose their course. At this phase, the sailors will consider the problems raised by Brennan and Hamlin. Should the ship's course (constitution) be chosen by a navigation committee small enough to avoid the problems of expressive preferences, or by a committee made-up of the whole?

We argue that expressive considerations will continue to dominate at the meta-constitutional phase. The sailors will never vote in favor of binding themselves against their expressive preferences at the meta-constitutional level for the same reasons that they will always vote in accordance with those same expressive preferences at the constitutional level. Supporting one's expressive preferences is expressively appealing. The sailors are rational and know that supporting the empowerment of a navigation (constitutional) committee chosen by lot means thwarting their expressive preferences. 
Additionally, they know that the instrumental interests of the navigation committee may not be perfectly aligned with their own, given the existence of the Isle of Slavers. Hence, we argue that initiatives aimed at truncating expressive preferences at the constitutional level are unlikely to be supported by the electorate; taming expressive preferences is not expressively appealing.

In addition to choosing whether a committee of the whole or a small navigation committee will choose their course, the sailors at the meta-constitutional level can also specify the establishment of a course enforcement committee. The sailors worry that, should they establish a small navigation committee, that committee will have incentive to sell the remaining sailors into bondage at the Isle of Slavers. A conundrum is then faced. If they establish a small navigation committee without an enforcement committee, the navigation committee will most likely sell them to the slavers (Leviathan). If they bind the navigation committee with an enforcement committee (a judiciary that is selected by elected representatives), that enforcement committee cannot bind itself against the expressive preferences of the sailors, ${ }^{15}$ consequently, the enforcement committee will force the ship towards the sirens regardless of the course chosen by the navigation committee. So, establishing the small committee at best leads to equivalent outcomes and at worst leads to Leviathan. Let us take up each potential path in turn.

V.

Meta-Constitutional choice: Navigational Committee unbound

Let us specify for the moment that, somehow, the sailors overcame their expressive preferences and convened a navigational committee. They heeded the warnings of Brennan and Hamlin and 
selected by lot a navigational committee statistically representative of the membership of the crew (membership on the committee includes proportionate numbers of deck-hands, cabin boys, and other forms of crewmen). In fact, the other members of the crew were so concerned at their likely ex-post proclivity to seek to undermine the navigational choice of the committee, they lashed themselves to the mast prior to allowing the committee to meet.

The committee is decisive over the choice of course, and each committee member is highly likely to be decisive. While all committee members have expressive preferences favoring a course towards the sirens, the probability of being eaten by the sirens is high, as is the probability of each committee member proving decisive. The voting calculus (shown explicitly in the case of popular constitutional choice, below) leads them to reject visiting the sirens.

While the committee is representative of the interests of all of the members of crew, their admission into the navigation committee creates a new interest for them; specifically, they each have an interest in making the members of the committee as well off as possible. Self-interest dominates, despite the constitutional move. Consequently, the choice between a return home to Greece and a trip to the Isle of Slavers is a relatively simple one. The committee chooses to take the bound members of the crew to the Isle of Slavers, then return to Greece and claim the rest of the crew was lost at sea. The choice of an unbound constitutional committee leads to Leviathan. 
VI. Meta-Constitutional Choice: the constrained Constitutional Committee.

The sailors at the meta-constitutional level are rational. They realize the existence of the Isle of Slavers, and the incentives facing the navigation committee. Consequently, they delegate the choice of course to the navigational committee, but they do not bind themselves against forcibly punishing the navigational committee should they spot the coastline of the Isle of Slavers. The navigational committee consequently chooses the path that leads home to Greece. The crew accepts the committee's decision at first, but quickly the more boastful crewmembers begin talking of the glories of the Sirens' song, and the honor they would gain by hearing it. Soon, the whole crew is enflamed with talk of the Sirens' song. The navigational committee reminds the crew that the choice of course was left to the committee. The crew then reminds the committee that the committee is greatly outnumbered, and that the crew wishes to hear the Sirens' song. A popular constitutional amendment is passed dictating that the ship's course to Greece must pass by the Isle of the Sirens.

The meta-constitutional phase can lead to two outcomes. In the first case, the metaconstitutional choice and constitutional choice are binding. The small committee is given both the power to choose the constitution and the power to enforce it. The committee quickly establishes itself as Oligarch. In the second case, the small committee is delegated the choice of constitution, but not the power of enforcement. The chosen constitution then cannot bind unless it accords with the preexisting expressive preferences of the electorate; in short, the outcome of delegation is identical to the outcome under popular constitutional choice. 
VII.

\section{Constitutional Choice}

As we argued above, meta-constitutional choice leads either to Leviathan or to an outcome identical to popular constitutional choice. The navigational committee either leads the ship to the Isle of Slavers, or to the Sirens. When instead the committee of the whole chooses the ship's course [constitution], the ship sails to the Sirens. For each individual sailor, the probability of decisiveness is low enough that the expressive benefits derived from a vote heeding the sirens' call swamps the risks of being eaten. Ulysses commands a large ship; hence, the probability that any sailor's vote proves decisive approaches nil. Each sailor can, at no personal cost, benefit from expressing his preference for hearing the sirens. The expected benefits of voting for steering the ship towards the slavers is negative in both expressive and instrumental terms and the sailors do not consider voting for such a course. The sailors overwhelmingly vote in favor of the course leading towards the sirens. Until they see a coastline, however, the sailors cannot tell whether their navigator has in fact led them to the Sirens. The navigator's choice corresponds to in-period politics.

VIII.

$$
\text { In-Period Politics }
$$

The ultimate decision over the ship's course will be made by its navigator, who is the only crew member who knows the sea routes that lead to Greece, the Sirens and the Slavers, and who is able to deceive our sailors about their true course. While mandated to sail to the Sirens', he may instead choose the Slavers, or to return home to Greece. As the ship approaches any of our three potential destinations, the outcome becomes irreversible - the ship is sighted from land at the same time as the 
sailors recognize the coastline. If they reach the Sirens, sailors and navigator alike face an equal chance of being devoured. The sailors can punish the navigator if they see that the coastline is not that of the Sirens.

The navigator's choice will also be dictated by an expected benefits calculation. In this case, our navigator must weigh the probability of death resulting from a course sailing near the sirens against the probability and severity of punishment from the crew resulting from his two potential paths of deviation (towards the Slavers or towards Greece). If the crew has signaled that the navigator would be punished severely for any deviation from the stated course, regardless whether the coast reached is that of Greece or that of the Isle of Slavers, then the navigator's calculus largely reduces to his estimation of the threat of death from the Sirens versus the punishment meted out by the crew if he brings them to the slavers. If the Sirens are dangerous enough, the navigator will sell the crew into slavery. If instead the navigator expects much harsher punishment for bringing the ship to the Isle of Slavers than for sailing home to Greece, the ship will be more likely to return home safely. In the case above, the optimal result (returning to Greece) obtains only if the navigator is allowed to shirk, but not shirk too much. ${ }^{16}$ IX.

Home from the Odyssey

Bringing our example back to the real world, our constitutional convention can choose to ratify a document embodying their noblest expressive preferences, or they can choose one instead that shuns their expressive preferences in favor of instrumental concerns. The constitutional convention of the 
whole will always make the expressively-appealing choice. Delegation to a small group can solve the problem of expressive considerations contaminating constitutional choice, but only at the cost of potentially creating an Oligarch. Making the decision of the small committee less than binding ${ }^{17}$ reintroduces expressive preferences and eliminates whatever benefit was sought through recourse to the small constitutional committee. Such a course may remain preferable to that of the Oligarch.

The worst-case logic characteristic of constitutional political economy suggests that either instrumental or expressive preferences will rear their head - ugly or otherwise - at the metaconstitutional, constitutional, and in-period stages. Ruling out oligarchy, the enacted constitution will necessarily reflect expressive preferences. Traditionally, CPE accounts have invoked a veil of uncertainty to separate decision-makers from their post-constitutional instrumental interests. There appears little way to adequately temper the lure of instrumental in-period interests, however, without allowing expressive preferences to enter the analysis center-stage.

The prevalence of expressive preferences at the constitutional stage may, assuming the chosen constitution $i s$ binding, generate a far worse outcome than that generated by day-to-day in-period politics. ${ }^{18}$ Indeed, given such a possibility, any difficulties in ex-post constitutional enforcement may prove second-best efficient - the day-to-day workings of in-period politics can serve to mitigate the welfare losses otherwise generated by an 'inefficient' constitution. Equally, where instrumental interests prevail at the constitutional stage, enforcement problems likewise possess efficiency properties. How to escape from the instrumental-expressive dilemma? Buchanan (2001 [1996], 275) provides a characteristically pungent suggestion: 
"As the historical experience of many countries suggests, constitutions can be reformed without being effectively enforced. Perhaps more important than formal constitutional changes are changes in ethical attitudes that would make attempted reforms workable ... There must be some general understanding that exploitation implemented through politics is just as immoral as exploitation implemented in the private sector" (italics added).

What are apparently required are the "right" kind of expressive preferences; what Buchanan elsewhere refers to as a "genuine "constitutional attitude," a proclivity or tendency to examine issues from a constitutional perspective, as opposed to the pragmatic, short-run, utilitarian perspective that seems to characterize ... day-to-day political discussion and action" (Buchanan [2001 (1981)], 42). It remains an open question which endeavour would prove the more fruitful: the engendering of the "right" preferences among the electorate, or the transformation of public servants from men into angels. The first change would steer the constitutional ship away from the Scylla of expressive preferences, while the second would prevent the Charybdis of the drafters' instrumental interests from dashing the ship. Either transformation would prove sufficient to prevent the ship from foundering though both seem to fall into the category of "hard problems". 


\section{Endnotes}

${ }^{1}$ The authors thank Geoffrey Brennan, Loren Lomasky, Dan Sutter, Colin Jennings, Bry an Cap lan, Tyler Cowen, and participants at the 2003 Public Choice Meetings for useful comments and discussion.

${ }^{2}$ See McGuire and Ohsfeldt $(1986,1989)$ for example.

${ }^{3}$ Mulligan and Hunter (2003) discuss the theoretical and empirical evidence regarding the probability of individual voter decisiveness.

${ }^{4}$ Brennan and Lomasky $(1993,124,224)$ make first use of the term, though Brennan and Hamlin (2000) attribute the term to Hartmut Kliemt.

${ }^{5}$ Imagine, for instance, the costs of holding the belief that a large dose of arsenic is the appropriate cure for a headache. Public opinion on questions of economic policy are frequently as wrong, but individuals do not personally bear the costs of such beliefs as they are not decisive in seeing those beliefs turned into policy. See Caplan (2002).

${ }^{6}$ Dennis Mueller's luncheon address at the 2003 Public Choice Society meetings is instructive here.

${ }^{7}$ Levy (1989) explains why the use of the Athenian lot was sensible in the case of bimodality.

${ }^{8}$ William Paley's remarks regarding in-period politics are apposite to the constitutional dilemma: "Where the constituents are numerous ... each voter considering his single suffrage as too minute a portion of the general interest to deserve his care or attendance ... [if] we contract the representation within a compass small enough to admit of orderly debate, the interest of the constituent becomes too small, of the representative too great." [2002 (1785)]: 324). 
9 Attacking James Mill's advocacy of democratic reform (an advocacy resting upon a worst-case theory of government), M acaulay countered: "When private men, they [the members of the imagined constitutional convention] may have been zealous for the interests of the community. When candidates, they may have pledged themselves to the cause of the constitution. But as soon as they are a convention, as soon as they are separated from the people, as soon as the supreme power is put into their hands, commences that interest, op posite to the interests of the community, which must according to Mr. Mill, produce measures opposite to the interests of the community.” (Macaulay [1978 (1829)], 114-115).

${ }^{10}$ Given that the answer begs obvious questions, and that no att empt is made to finesse the problem, one wonders whether Brennan and Hamlin here are not actually seeking to point out a serious flaw in constitutional political economy rather than p rop ose a remedy. While one might posit a theoretical veil as solution in the absence of expressive voting problems, it is wholly insufficient in the context of expressively-voting delegates.

${ }^{11}$ See, for example, Elster (2000) and Buchanan ([2001 (1994)], 398-416). Of course, it remains unresolved why the accepted constitution will prove binding on the future generation. "We" might choose to implement constitutional rules that apply with a time-lag but why are "they" any more likely at time $\mathrm{T}+2$ to find the imposition of "our" rules acceptable than we ourselves at time T?

${ }^{12}$ Note, of course, that if the two-generation delay is sufficient to separate the framers from their interests, it will also invoke expressive considerations.

${ }^{13}$ Terry Moe (1990), for example argues that the Presidential veto gives the Executive strong influence in shaping legislation.

${ }^{14}$ Consider it thusly. The Course chosen dictates the overall framework within which the society of the ship travels. It dictates simply the port towards which the ship must sail. In-period politics, in this case, will correspond to the day-to-day workings of the ship: how best to navigate around storms, when the nets will be cast 
out for fish, and so on. Brennan and Buchanan suggest a fixed monetary constitution (1980); we similarly here suggest a fixed Course constitution.

${ }^{15}$ Flemming and Wood (1997), for example, find that the Sup reme Court is directly responsive to changes in voter preferences; many, including Nelson (1988) discuss the "switch in time that saved nine" in which Roos evelt threat ened to stack the Court if it failed to provide favorable rulings. The ship's enforcement committee here will similarly be unable to bind itself against the expressive preferences of the sailors.

${ }^{16}$ A similar case may hold in normal electoral politics. Election campaigns are fought in expressive space and consequently involve the making of campaign pledges that run contrary to the health of the economy. Voters, how ever, punish incumbents when the economy fares poorly (Fiorina 1981, Kieweit 1983). Consequently, an incumbent administration faces an incentive to deviate from expressive voter preferences in efficiency increasing ways.

${ }^{17}$ Note, of course, Tullock's caveat on constitutionalism: "the view that the government can be bound by sp ecific provisions [constitutional rules] is naïve. Something must enforce those rules, and whatever enforces them is itself unbounded" (Tullock 1987, 87).

${ }^{18}$ All required for this case to obtain are expressive preferences more strongly divergent from instrumental preferences at the constitutional phase, or equally divergent expressive preferences more strongly held. 
XI. Bibliography

Brennan, G., and Kliemt, H. (1990) “Logo Logic.” Constitutional Political Economy. 1(1):125127.

Brennan, G. and Buchanan, J.M. [2000 (1980)] The Power to Tax. Indianapolis: Liberty Press.

Brennan, G. and Hamlin, A. (2000) Democratic Devices and Desires. Cambridge: Cambridge University Press.

Brennan, G. and Hamlin, A. (2002) 'Expressive Constitutionalism.” Constitutional Political Economy. 13(4): 299-311.

Brennan, G. and Lomasky, L. (1993) Democracy \& Decision: The Pure Theory of Electoral Preference. Cambridge: Cambridge University Press.

Buchanan, J.M. [2001 (1981)] “Constitutional Restrictions on the Power of Government." In Choice, Contract, and Constitutions. Indianapolis: Liberty Press.

Buchanan, J.M. [2001 (1994)] "Lagged Implementation as an Element in Constitutional Strategy.” In Choice, Contract, and Constitutions. Indianapolis: Liberty Press.

Buchanan, J.M. [2001 (1996)] “Distributional Politics and Constitutional Design.” In Choice, Contract, and Constitutions. Indianapolis: Liberty Press. 
Buchanan, J.M. and Tullock, G. [1997 (1962)] The Calculus of Consent. Ann Arbor: University of Michigan Press.

Caplan, B. (2000) "Rational Irrationality: A Framework for the Neoclassical-Behavioral Debate." Eastern Economic Journal 26(2): 191-211.

Caplan, B. (2001) "Rational Irrationality and the Microfoundations of Political Failure.” Public Choice. 107(3/4):311-31.

Caplan, B. (2002) "Systematically Biased Beliefs about Economics: Robust Evidence of Judgmental Anomalies from the Survey of Americans and Economists on the Economy." Economic Journal 112: 433-58.

Elster, J. (2000) Ulysses Unbound. Cambridge: Cambridge University Press.

Fiorina, M.P. (1981) 'Retrospective Voting in American National Elections.” New Haven: Yale University Press.

Flemming, R.B. and Wood, B.D. (1997) 'The Public and the Supreme Court: Individual Justice Responsiveness to American Policy Moods", American Political Science Review. 41(2): 468-98.

Kiewiet, D.R. (1983) "Macroeconomics and Micropolitics: The Electoral Effects of Economic Issues." Chicago: University of Chicago Press. 
Levy, D.M. (1989) “The Statistical Basis of Athenian-American Constitutional Theory.” Journal of Legal Studies. 18 (January): 79-103.

McGuire, R.A. and Ohsfeldt, R.L. (1986) “An Economic Model of Voting Behavior over Specific Issues at the Constitutional Convention of 1787." Journal of Economic History 46(1): 79111.

McGuire, R.A. and Ohsfeldt, R.L. (1989) “Self-Interest, Agency Theory, and Political Voting Behavior: The Ratification of the United States Constitution.” American Economic Review. 79(1): 219-34.

Macaulay, T. B. [1978 (1829)] “Mill's Essay on Government: Utilitarian Logic and Politics.” In Utilitarian Logic and Politics: James Mill's 'Essay on Government', Macaulay's critique, and the ensuing debate, edited by J. Lively and J. Rees. Oxford: Clarendon Press.

Moe, T. (1990) "Political Institutions: The Neglected Side of the Story." Journal of Law, Economics and Organization 6:213-54.

Mulligan, C.B. and Hunter, C.G. (2003) 'The Empirical Frequency of a Pivotal Vote." Public Choice $116(1 / 2): 31-54$.

Nelson, M. (1988) “The President and the Court: Reinterpreting the Court-packing Episode of 1937.” Political Science Quarterly. 103(2):267-93. 
Paley, W. [2002 (1785)] The Principles of Moral and Political Philosophy. Indianapolis: Liberty Press.

Tullock, G. (1987) “The Calculus after 25 years.” Cato Journal. 7(2):313-321. 